\title{
Alström Syndrome
}

Alström Syndrome is an autosomal recessive, single gene disorder caused by mutations in ALMS1 (Chr 2p13), a novel gene of currently unknown molecular function. Alström Syndrome is multisystemic, with cone-rod retinal dystrophy leading to juvenile blindness, sensorineural hearing loss, obesity, insulin resistance with hyperinsulinemia, and type 2 diabetes mellitus. Very high incidences of additional disease phenotypes that may severely affect prognosis and survival include endocrine abnormalities, dilated cardiomyopathy, pulmonary fibrosis and restrictive lung disease, and progressive hepatic and renal failure. Other clinical features in some patients are hypertension, hypothyroidism, hyperlipidemia, hypogonadism, urological abnormalities, adult short stature, and bone-skeletal disturbances. Most patients demonstrate normal intelligence, although some reports indicate delayed psychomotor and intellectual development. The life span of patients with Alström Syndrome rarely exceeds $\mathbf{4 0}$ years. There is no specific therapy for Alström Syndrome, but early diagnosis and intervention can moderate the progression of the disease phenotypes and improve the longevity and quality of life for patients.

\section{In brief}

- Alström Syndrome is a rare, multisystemic genetic disorder exhibiting cone-rod dystrophy (early nystagmus, blindness), hearing loss, obesity, insulin resistance and hyperinsulinemia, type 2 diabetes mellitus, dilated cardiomyopathy, and progressive hepatic and renal dysfunction.

- The clinical features, time of onset, and severity can vary greatly among and within families.

- Early diagnosis is important but difficult because many of the phenotypes are not present in infancy but develop throughout childhood and adolescence.

- Mutations in ALMS1 that cause Alström Syndrome are clustered and exhibit relatively few genotype-phenotype correlations.

- There is no evidence for genetic heterogeneity.

- The function of ALMS1 is not yet known, although a role in formation, maintenance, and function of cilia is suggested.

- Management of the syndrome should include vigilant monitoring and treatment of the emerging clinical manifestations as a patient grows and develops.

\begin{abstract}
Jan D Marshall*,1 , Sebastian Beck ${ }^{2,3}$, Pietro Maffei ${ }^{4}$ and Jürgen K Naggert ${ }^{1}$
${ }^{1}$ The Jackson Laboratory, Bar Harbor, ME, USA; ${ }^{2}$ Department of Neonatology and Paediatric Intensive Care, Ernst-Moritz-Arndt-University, Greifswald, Germany; ${ }^{3} \mathrm{CGC}$, Centro Genética Clínica, Porto, Portugal; ${ }^{4}$ Department of Medical and Surgical Sciences, University School of Medicine, Padua, Italy
\end{abstract}

European Journal of Human Genetics (2007) 15, 1193-1202; doi:10.1038/sj.ejhg.5201933; published online 17 October 2007

Keywords: Alström Syndrome; ALMS1

*Correspondence: JD Marshall, Genetics Coordinator Alstrom Syndrome Studies, The Jackson Laboratory, 600 Main Street, Bar Harbor, ME 04609, USA.

Tel: + 1207288 6385; Fax: + 1207288 6078;

E-mail: jan.marshall@jax.org

Received 18 April 2007; revised 25 August 2007; accepted 31 August 2007; published online 17 October 2007

\section{Introduction}

Alström Syndrome (ALMS1, MIM \#203800) is a rare monogenic condition caused by mutations in the gene ALMS1. Approximately 450 cases have been identified since the condition was first described in $1959 .^{1}$

Diagnosis of Alström Syndrome can be difficult because some features begin at birth and others emerge as the child develops. There is considerable variation both within and among families. The major phenotypes usually observed in children with Alström Syndrome include cone-rod retinal dystrophy beginning in infancy and leading to eventual juvenile blindness, sensorineural hearing impairment, insulin resistance, and obesity. In some cases, infants present with congestive heart failure $(\mathrm{CHF})$ due to dilated cardiomyopathy (DCM). As patients reach adolescence, more of the major phenotypes develop, including type 2 diabetes mellitus (T2DM), hypertriglyceridemia, and adolescent-onset DCM. Short stature, scoliosis, alopecia, 
and male hypogonadism and hyperandrogenism in female patients may be present when patients reach adulthood. Pulmonary, hepatic, and renal phenotypes are progressive. Fibrosis in multiple organs has been described. ${ }^{2}$

\section{Clinical overview Sensory loss}

The retinal dystrophy in Alström Syndrome usually develops within a few weeks after birth and virtually all children exhibit low vision within the first year of life. The first symptoms are nystagmus and extreme photodysphoria or light sensitivity. Vision may be aided in the first few years, particularly if the child is given prescription dark, red-tinted glasses. Cataract is a common finding and some patients might transiently benefit from its treatment/removal. In Alström Syndrome, cone dystrophy occurs first, so the vision that children experience in early childhood comes primarily from the rods. As retinal dystrophy progresses, the photodysphoria diminishes. Although the rate of progression of vision loss can be variable, eventually all children become blind. By 9 years of age, approximately one-third of patients are totally blind; $50 \%$ by age 12 , and $90 \%$ by age 16 . Retinal changes include attenuated vessels, pale optic discs, and partial atrophy of the retinal pigment epithelium. Pathological studies show a reduction of cell layers in the posterior retina and depletion of peripheral cells, the outer nuclear layer, and photoreceptors. ${ }^{2}$

Most patients develop mild-to-moderate bilateral sensorineural hearing loss that is slowly progressive, particularly in the high-frequency range. Some (about 10\%) progress to profound deafness and must rely on tactile signing for communication. Although differences in acuity exist, most patients report some degree of hearing loss by age 7 . There is evidence that vestibular function is abnormal in some patients. Because hearing loss develops gradually and the onset is post-lingual, children typically do not experience the speech problems often associated with deafness. There is a high incidence of otitis media and fluid retention along with a high susceptibility to glue ear, which compounds the existing sensorineural impairment.

\section{Cardiac function}

Dilated cardiomyopathy occurs in approximately twothirds of patients with Alström Syndrome. ${ }^{2}$ The majority of those $(>60 \%)$ develop sudden onset CHF during their first months of life. A life-threatening episode of CHF can be one of the first symptoms noticed in affected infants, even before nystagmus is observed. In many infants, cardiac function improves by age 3 and remains stable for many years with 'low normal' function. A sudden recurrence of DCM/CHF may follow during adolescence or adulthood. Other patients develop DCM for the first time as adolescents or adults. Therefore, all Alström Syndrome patients are at risk for developing DCM at any time.

\section{Endocrinological disturbances}

Obesity in Alström Syndrome is an early and consistent feature observed in nearly all affected children. Excess weight gain does not usually begin until approximately 6 months to 1 year of age and may moderate after puberty. Wide shoulders, a barrel chest, a 'stocky' build, and truncal obesity are typical. Although hyperphagia and food obsession are common complaints, the cause of obesity is unknown. Based on the expression pattern of Alms 1 in the mouse brain, a hypothalamic origin is possible.

Insulin resistance and hyperinsulinemia, two of the earliest metabolic changes in Alström Syndrome, have been observed in patients as young as 1 year of age, before the child is obese. Most children will eventually develop T2DM, but there is a great deal of variability in the age of onset. Diabetes may be present as early as the age of 4 , with the median age of onset at 16 years. Acanthosis nigricans, a skin condition sometimes associated with obesity, hyperinsulinemia, and insulin resistance, is described in about one-third of patients, whether or not they have diabetes.

Growth hormone deficits and disturbances in the growth hormone/insulin-like growth factor I axis have been reported in a number of cases. ${ }^{3-5}$ Length and weight at birth are within the normal range. Children grow rapidly and are initially tall for their age ( $>50$ th centile), with 2-3 years advanced bone age, but early closure of the growth plates results in height below the 50th centile by age 14-16 years. $^{2}$ Male adolescents have small testes and penises, impaired or delayed puberty, gynecomastia, and low sperm count. Testicular biopsies show atrophy with few Leydig cells and fibrosis in the tubules. Normal-to-high folliclestimulating hormone (FSH) and luteinizing hormone (LH) levels and low testosterone levels indicate primary hypogonadism. Males are unlikely to be fertile, but have normal secondary sexual characteristics such as facial and abdominal hair. Potency and sexual drive have not been thoroughly investigated.

In female adolescents, sexual development usually progresses normally and menarche is not delayed (average age 12 years). In a few patients, puberty has occurred early (age 6-10) and breast development has been delayed. Secondary sexual characteristics such as axillary and pubic hair are normal. The external genitalia, uterus, and fallopian tubes are normal, but menstruation is often scant, sporadic, or irregular. Baseline FSH and LH in female adolescents are usually in the normal range; however, some evidence of primary hypogonadism has been reported. ${ }^{4}$ Increased androgen production and hirsuitism are common. A relatively high frequency $(>20 \%$ of female patients) of ovarian cysts is reported, which may be associated with obesity and hyperinsulinemia.

Hyperlipidemia, particularly hypertriglyceridemia, can be present from early childhood. In some patients, a sudden, rapid rise in triglycerides places them at risk for pancreatitis. ${ }^{6}$ Other features in Alström Syndrome, such as 
hyperinsulinemia, may also contribute to the elevated triglycerides.

A hypothyroid condition, mostly primary (low free thyroxine (FT4), high thyroid-stimulating hormone (TSH)), is observed in approximately $20 \%$ of patients. Subclinical hypothyroidism in about $30 \%$ of patients and isolated incidents of hyperthyroidism have been observed. ${ }^{4}$ The mechanism of the hypothyroidism remains unknown, although it could be hypothesized that fibrotic infiltrations in the thyroid gland play a role.

\section{Anthropometrics}

There is no facial dysmorphology, but patients have distinctive facial characteristics including deep-set eyes with a rounded face, thick ears, premature frontal balding, and thin hair. Hyperostosis frontalis interna is reported in many patients. Dental anomalies include discolored teeth, gingivitis, a large space between the front teeth, and extra or missing teeth. ${ }^{7}$

Most children have characteristic wide, thick, flat feet, and short stubby fingers and toes with no polydactyly or syndactyly. Rare cases of digit anomalies have been reported. ${ }^{2}$ Thoracic and lumbar scoliosis and kyphosis commonly develop in the early teenage years and can progress rapidly. Many patients have a 'buffalo hump' of increased fatty tissue above the shoulders.

\section{Hepatic dysfunction}

Nearly all patients with Alström Syndrome are at risk for some degree of liver involvement with a highly variable age of onset, clinical course, and prognosis. Initially, transaminases and gamma-glutamyl transpeptidase (GGT) are elevated but overt clinical manifestations are absent. The liver and spleen may be enlarged, and ultrasound may show evidence of steatosis. Later in the disease process, liver function is disturbed with altered prothrombin values or elevated International normalized ratio (INR) and ammonia. Hepatic inflammation and fibrosis, portal hypertension, hepatosplenomegaly, cirrhosis, esophageal varices, and liver failure can be late clinical signs. Upper GI hemorrhage due to portal hypertension has led to death in several patients. It is not yet known why some children with Alström Syndrome develop serious liver complications while others do not.

\section{Renal dysfunction}

Slowly progressive nephropathy, progressive glomerulofibrosis, and a gradual destruction of the kidneys are a major feature in adult patients with Alström Syndrome. Age of onset, progression rate, and severity are variable. Patients may have symptoms ranging from chronic mild kidney dysfunction to end-stage renal failure. Histopathologic changes include hyalinization of tubules and interstitial fibrosis. ${ }^{2,8}$ There is evidence suggesting that the position of the alteration in ALMS1 may play a role in the severity of the renal disease. ${ }^{25}$

\section{Urological manifestations}

Patients can experience varying degrees of urinary problems. Minor symptoms include urinary urgency, difficulty initiating or poor flow, long intervals between voiding, incomplete voiding or abdominal pain before or during urination. There can be an unusual changing presentation, switching from retention to increased frequency, and incontinence. Recurrent urinary tract infections or cystitis are common in both male and female patients. Urethral strictures have also been described and fibrotic infiltrations have been noted histopathologically ${ }^{2,9}$ A subset of patients have developed more severe complications such as marked frequency and urgency, incontinence, and significant perineal or abdominal pain requiring surgical intervention.

\section{Pulmonary function}

Chronic respiratory illness is one of the most frequent complaints. Symptoms range from frequent colds and flu, to chronic bronchitis, sinusitis, and recurrent bouts of pneumonia. The chronically inflamed airways are hyperreactive and highly sensitive to triggering or irritating factors. As inflammation continues, the lungs are infiltrated by fibrotic lesions. Some older patients manifest chronic obstructive pulmonary disease or acute respiratory distress syndrome. Sudden reduced blood-oxygen saturation in patients with respiratory infection has contributed to the death of some patients.

\section{Developmental delays}

Hearing and vision deficits probably contribute to the early developmental, receptive language, and learning delays seen in many young children with Alström Syndrome. Children with a receptive language deficit also tend to have an expressive language delay. Most children have normal intelligence (IQ), but motor milestones, in particular sitting, standing, and walking, are typically delayed by 1-2 years and there may be deficits in coordination, balance, and fine motor skills. Intellectual delays and behavioral issues in rare cases have resulted in a diagnosis of mental retardation. A range of autism-spectrum behavior has been observed in some patients.

\section{Other systemic disturbances}

Hypertension is seen in about $40 \%$ of patients, sometimes as early as 2 years of age. Kidney damage and renal dysfunction can account for a large share of secondary hypertension.

Neurological symptoms such as absence seizures, ataxia, and unexplained muscular pain have been reported. Sleep disturbances have also been documented. 


\section{Diagnostic criteria}

Alström Syndrome is characterized by a constellation of progressive and highly variable disease symptoms. Diagnosis is made on the basis of clinical features observed, usually without genetic confirmation. Delay of onset of some of the characteristic features (T2DM, DCM/CHF, hepatic dysfunction, pulmonary, and renal disease) makes early differential diagnosis very difficult in young children, as many of the cardinal features do not become apparent until the teenage years. As the child grows, the characteristic pattern of Alström Syndrome evolves and the clinical picture becomes clearer. A diagnosis of Alström Syndrome is proven at any age when two ALMS1 mutations, each coming from one parent, have been identified in the patient. Because two disease-causing mutations are not always easily identified, we have established a set of diagnostic criteria suggested for infants through 2 years, children aged 3-14 years, and adolescents/adults over 15 years (Table $1 \mathrm{a}$ ). To aid the clinician in making an early diagnosis, we have designated 'major' criteria for a diagnosis, along with 'minor' criteria that can be used as evidence of Alström Syndrome, according to age.

In infancy through 2 years of age, a diagnosis should be considered if two major criteria are present (a mutation in one allele of ALMS1 and early cone-rod retinal degeneration) or if one major criteria is present along with obesity or DCM. In the case of infants and toddlers, we encourage that a diagnosis based upon clinical findings should also be re-examined when the child is older. We suggest that a clinical diagnosis can be made in children aged 3-14 with two of the major criteria and at least one minor criteria. At age 15 through adulthood, a diagnosis should be made in a patient with two major and two minor criteria, or one major and four minor criteria. Other age-appropriate, but variable, supportive evidence is also listed (Table 1a).

Genetic testing should be undertaken when the combination of major (vision) and minor criteria does not permit a clinical diagnosis. The identification of a single mutated ALMS1 allele would confirm the diagnosis. The same applies if there is a family history of Alström Syndrome and a combination of age-appropriate major or minor criteria, but no diagnosis. Circumstances indicating genetic testing are detailed in Table $1 \mathrm{~b}$.

\section{Differential diagnosis}

The similarity to other syndromes and delay in onset of some of the clinical features in Alström Syndrome often results in misdiagnosis. ${ }^{10-15}$ Most often, photophobia in infancy leads to an incorrect first diagnosis of Leber congenital amaurosis or achromatopsia. Presentation of more features, such as childhood obesity and T2DM, sometimes lead physicians to consider a diagnosis of Bardet-Biedl Syndrome (BBS). The presence of DCM in infancy or adolescence, early hearing loss in most patients, and the absence of distal digit abnormalities can be helpful in distinguishing Alström Syndrome from BBS. Biemond II Syndrome, Wolfram Syndrome, Cohen Syndrome, sporadic infantile DCM, and mitochondrial disorders have also been considered as a diagnosis. A detailed comparison of features observed in Alström Syndrome and other disorders with phenotypic overlap is shown in Table 2. Clinical features such as the early age of onset of cone dystrophy, hearing loss and obesity in childhood, DCM, T2DM, normal intelligence (but delay of developmental milestones), absence of digital anomalies, advanced bone age with reduced final adult height can be helpful in distinguishing this syndrome from closely related disorders. ${ }^{16}$

\section{Molecular and genetic basis of the disease}

Alström Syndrome is the consequence of recessively inherited mutations in a single gene, ALMS1, located on the short arm of chromosome 2. Parents are obligate carriers of a single copy of the altered gene and have no reported heterozygous phenotypic characteristics. Male and female individuals are affected with equal probability (1:1 ratio) and there is no one ethnic group more likely to carry ALMS1 mutations.

ALMS1 is comprised of 23 exons encoding a protein of 4169 amino acids. The ALMS1 protein is ubiquitously expressed and localizes to centrosomes and basal bodies of ciliated cells, perhaps playing an important role in cilia function and intraflagellar transport. ${ }^{17,20}$ RNA interference knockdown experiments indicate that a total lack of ALMS1 impairs cilia formation. ${ }^{19}$

To date, the mutations reported in ALMS1 have been nonsense and frameshift variations (insertions or deletions) and one reciprocal translocation that are predicted to cause premature protein truncation. ${ }^{17,18,21-25}$ In total, 79 disease-causing variants have been reported. ${ }^{25}$ The variants are primarily clustered in exons 16, 10, and 8, but less common mutations also occur in exons 12 and 18. Founder effects are reported in families of English and Turkish descent. In addition, numerous single-nucleotide polymorphisms have been identified, the functional significance of which is unclear.

The mechanisms by which disease alleles of ALMS1 cause the various pathologies observed in Alström Syndrome remain unknown and identification of pathogenic mutations in ALMS1 has not led to any genotype-specific treatments. $^{24,26}$

\section{Management and treatment}

There is, thus far, no treatment that can cure Alström Syndrome or prevent or reverse the medical complications. Children with Alström Syndrome require a detailed history and thorough initial assessment along with intensive medical management and multidisciplinary follow-up to anticipate and detect the complications that can be 
Table 1a Diagnostic criteria for Alström Syndrome

\begin{tabular}{|c|c|c|c|}
\hline & Birth - 2 years $^{\mathrm{a}}$ & $3-14$ years & 15 years - adulthood \\
\hline Proof ${ }^{b}$ & 2 ALMS1 mutations & 2 ALMS1 mutations & 2 ALMS1 mutations \\
\hline Minimum & (a) 2 major criteria & (a) 2 major criteria & (a) 2 major and 2 minor criteria \\
\hline $\begin{array}{l}\text { diagnosis } \\
\text { requires }\end{array}$ & $\begin{array}{l}\text { (b) } 1 \text { major and } 2 \text { minor } \\
\text { criteria }\end{array}$ & (b) $\stackrel{\text { or }}{1}$ major and 3 minor criteria & (b) 1 major and 4 minor criteria \\
\hline Major criteria & $\begin{array}{l}\text { - ALMS1 mutation in } 1 \\
\text { allele and/or family history } \\
\text { of Alström Syndrome } \\
\text {-Vision (nystagmus, } \\
\text { photophobia) }\end{array}$ & $\begin{array}{l}\text { - ALMS1 mutation in } 1 \text { allele and/or } \\
\text { family history of Alström Syndrome } \\
\text {-Vision (nystagmus, photophobia, } \\
\text { diminished acuity, if old enough for } \\
\text { testing: cone dystrophy by ERG) }\end{array}$ & $\begin{array}{l}\text {-ALMS1 mutation in } 1 \text { allele and/or family } \\
\text { history of Alström Syndrome } \\
\text { Vision (history of nystagmus in infancy/ } \\
\text { childhood, legal blindness, cone and rod } \\
\text { dystrophy by ERG) }\end{array}$ \\
\hline Minor criteria & $\begin{array}{l}\text { - Obesity } \\
-\mathrm{DCM} / \mathrm{CHF}\end{array}$ & $\begin{array}{l}\text { - Obesity and/or insulin resistance } \\
\text { and/or T2DM } \\
\text { - (history of) DCM/CHF } \\
\text { - Hearing loss } \\
\text { - Hepatic dysfunction } \\
\text { - Renal failure } \\
\text { - Advanced bone age }\end{array}$ & $\begin{array}{l}\text { - Obesity and/or insulin resistance } \\
\text { and/or T2DM } \\
\text { (history of) DCM/CHF } \\
\text { - Hearing loss } \\
\text { - Hepatic dysfunction } \\
\text { - Renal failure } \\
\text { - Short stature } \\
\text { - Males: hypogonadism } \\
\text { Females: irregular menses and/or } \\
\text { hyperandrogenism }\end{array}$ \\
\hline $\begin{array}{l}\text { Other variable } \\
\text { supportive } \\
\text { evidence }\end{array}$ & $\begin{array}{l}\text { Recurrent pulmonary } \\
\text { infections } \\
\text { Normal digits } \\
\text { Delayed developmental } \\
\text { milestones }\end{array}$ & $\begin{array}{l}\text { Recurrent pulmonary infections } \\
\text { Normal digits } \\
\text { Delayed developmental milestones } \\
\text { Hyperlipidemia } \\
\text { Scoliosis } \\
\text { Flat wide feet } \\
\text { Hypothyroidism } \\
\text { Hypertension } \\
\text { Recurrent UTI } \\
\text { Growth hormone deficiency }\end{array}$ & $\begin{array}{l}\text { Recurrent pulmonary infections } \\
\text { Normal digits } \\
\text { History of developmental delay } \\
\text { Hyperlipidemia } \\
\text { Scoliosis } \\
\text { Flat wide feet } \\
\text { Hypothyroidism } \\
\text { Hypertension } \\
\text { Recurrent UTI/urinary dysfunction } \\
\text { Growth hormone deficiency } \\
\text { Alopecia }\end{array}$ \\
\hline
\end{tabular}

${ }^{a}$ Diagnostic criteria in children should be re-evaluated when patient grows older.

b If two mutations are found, confirm one inherited from each parent.

Abbreviations: ERG, electroretinogram; T2DM, type 2 diabetes mellitus; DCM/CHF, dilated cardiomyopathy with congestive heart failure; UTI, urinary tract infections.

treated. Careful monitoring of the systemic manifestations and prompt intervention can generally improve the overall outcome. Social support might be needed for some individuals, especially at school. Table 3 details the recommended assessments and follow-up evaluations for patients with Alström Syndrome.

Management of the multiple sensory deficits is crucial in young children. Photophobia and nystagmus can be serious problems, particularly in younger children. Red-tinted prescription glasses are helpful in alleviating the distress children experience in bright lighting. Eventual total loss of vision should be expected; therefore, early mobility training and Braille or other non-visual language skills is important. Hearing can usually be effectively managed with hearing aids, but should be monitored regularly.

All patients with a diagnosis of Alström Syndrome should be regularly monitored for cardiac function by echocardiography. Long-term angiotensin-converting enzyme (ACE) inhibition is indicated for the patient with cardiomyopathy. Many patients respond to other medications, which favorably affect heart function, such as diuretics, digitalis, $\beta$-blockers, and spironolactone. Whether cardiac transplantation is a viable option is yet to be determined, due to the multisystemic involvement, particularly pulmonary, endocrine, and renal function. There has been one successful heart-lung transplantation reported in a patient with Alström Syndrome, but with no T2DM or significant renal failure. ${ }^{27}$

Weight reduction and physical exercise, classic advice for patients with metabolic disorders, are also important for individuals with Alström Syndrome, even though low vision can make some forms of exercise challenging. The responsiveness to treatment of hyperglycemia is variable. Younger patients rarely require insulin, but some patients require insulin in very-high doses long term. Many respond to insulin-sensitizing agents such as Metformin and/or thiazolidinediones (TZDs). However, this requires close monitoring of liver, cardiac, and renal function. Some 
Table 1b Indications for genetic testing for mutations in the ALMS1 gene ${ }^{\mathrm{a}}$

\begin{tabular}{|c|c|}
\hline Circumstance & Indications \\
\hline $\begin{array}{l}\text { Patients with a high clinical suspicion of having Alström } \\
\text { Syndrome (6-12 weeks for most mutations, up to over } \\
12 \text { months for complete screening) }\end{array}$ & $\begin{array}{l}\text { These patients should be considered for testing if the combination } \\
\text { of major and minor criteria does not permit a firm clinical diagnosis; } \\
\text { therefore, the finding of one mutation would establish the diagnosis } \\
\text { (Table 1a). }\end{array}$ \\
\hline
\end{tabular}

Patients with clinically established diagnosis of Alström Syndrome (6-12 weeks for most mutations, up to over 12 months for complete screening)

Carrier testing (2 weeks plus genetic counseling)

Presymptomatic testing in a newborn at risk (2 weeks plus genetic counseling, which should be offered during pregnancy)

Prenatal testing in an unborn at risk (2 weeks plus genetic counseling, which should be offered as early as possible)
Generally a molecular confirmation of the clinical diagnosis is not absolutely necessary; however, some exceptions may exist, such as (a). Genetic testing of the index patient is highly recommended before carrier testing in the family.

(b). Genetic testing of the index patient is highly recommended before prenatal or presymptomatic testing in the same family. (c). If appropriate medical support depends on a molecular diagnosis, genetic confirmation is indicated. Although we believe that this situation should never occur, for the individual patient it may be easiest to circumvent problems.

(d). If a patient with a clinical diagnosis grows older and fails to present minor diagnostic criteria, a genetic confirmation of the diagnosis is indicated.

Carrier testing should be limited to relatives preparing for prenatal or presymptomatic diagnosis.

Presymptomatic testing in a younger sibling of a child with Alström Syndrome is recommended, as an early diagnosis offers opportunity for raised awareness and early therapeutic intervention of potential complications such as DCM. Established rules for presymptomatic testing (including genetic counseling, two independent samples, and appropriate preparation for the test by testing the parents for carrier status) should be followed.

Can be offered in the context of genetic counseling according to national laws.

${ }^{a}$ Direct testing is always preferred over indirect prenatal testing and should be utilized whenever possible.

patients with severe hypertriglyceridemia responded to low-fat diet combined with statins and nicotinic acid. ${ }^{6}$

We suggest monitoring of both TSH and FT4 in the clinical setting because screening of TSH alone could be misleading. Thyroid function should be monitored closely in critical hospital settings. Replacement therapy with L-thyroxin and testosterone, when needed, are very effective and well-tolerated in the majority of patients. Both Metformin and/or estroprogestin compounds have been employed to manage irregular menses. Medical therapy directed to balance endocrine disorders might be useful to reduce fat mass, thus ameliorating the insulin-resistant state. Although, growth hormone therapy has been safely administered for long periods in some patients, it should be considered still investigational. The full balance between risks and benefits of growth hormone replacement has not yet been proven in Alström Syndrome.

Lack of coordination between bladder and urine outflow (detrusor-urethral dyssynergia) can be helped by intermittent self-catheterization of the bladder. Ileal diversion may be necessary in rare patients.

Fatty liver can progress to significant fibrosis, cirrhosis, and portal hypertension in Alström Syndrome. Aggressive treatment with variceal banding and $\beta$-blockers is warranted in patients with portal hypertension and varices. Patients may be candidates for a transjugular intrahepatic portosystemic shunt to decrease the risk of variceal bleeding. The effectiveness of liver transplantation has not been proven.

Because renal insufficiency develops slowly as the patient ages, regular testing of renal function is important. Fibrosis and glomerulosclerosis in the kidneys may lead to eventual renal failure. ACE inhibitors should be prescribed to preserve kidney function according to general guidelines. Renal transplantation has been successful in a few patients.

Alström Syndrome involves a number of interrelated changes which can compromise cardio-respiratory function, such as pulmonary fibrosis, DCM, and scoliosis, particularly with respiratory infection or routine surgical procedures. There is the potential for patients to become critically hypoxic and appropriate precautions should be taken. Considering the fact that Alström Syndrome patients are 'fragile' individuals, we encourage adherence to regular vaccinations especially against flu and hepatitis $B$ virus infections.

With any rare syndrome, there can be a sense of isolation and parents and families usually feel a need for both information and emotional support. This is particularly true with Alström Syndrome; therefore, families should be 
Table 2 Differential diagnosis of Alström Syndrome

\begin{tabular}{|c|c|c|c|c|c|c|c|}
\hline & $\begin{array}{l}\text { Alström } \\
\text { Syndrome }\end{array}$ & $\begin{array}{l}\text { Bardet-Biedl } \\
\text { Syndrome } \\
\text { (BBS \#1-12) }\end{array}$ & $\begin{array}{l}\text { Congenital } \\
\text { achromatopsia }\end{array}$ & $\begin{array}{l}\text { Leber congenital } \\
\text { amaurosis }(L C A)\end{array}$ & $\begin{array}{l}\text { Wolfram } \\
\text { (DIDMOAD) }\end{array}$ & $\begin{array}{l}\text { Cohen } \\
\text { Syndrome }\end{array}$ & $\begin{array}{l}\text { Biemond II } \\
\text { Syndrome }\end{array}$ \\
\hline OMIM & 203800 & 209900 & $\begin{array}{l}216900 \\
262300 \\
139340\end{array}$ & 204000 & 222300 & 216550 & 210350 \\
\hline Vision & $\begin{array}{l}\text { Cone dystrophy, } \\
\text { photophobia }\end{array}$ & $\begin{array}{l}\text { Night blindness, } \\
\text { rod-cone } \\
\text { dystrophy } \\
\text { (age 10-16) }\end{array}$ & Cone dystrophy & $\begin{array}{l}\text { Cone dystrophy } \\
\text { (infancy) }\end{array}$ & Optic atrophy & $\begin{array}{l}\text { Rod-cone } \\
\text { dystrophy }>5 \text { years } \\
\text { myopia, bulls-eye } \\
\text { maculopathy, } \\
\text { peripheral } \\
\text { vision loss }\end{array}$ & $\begin{array}{l}\text { Coloboma, } \\
\text { microphthalmia, } \\
\text { aniridia, cataract }\end{array}$ \\
\hline Cardiac & Yes & $\begin{array}{l}\text { Congenital heart } \\
\text { defects } \\
(5-10 \%)\end{array}$ & No & No & No & No & No \\
\hline Respiratory & $\begin{array}{l}\text { Pulmonary } \\
\text { failure, } \\
\text { recurrent } \\
\text { cough }\end{array}$ & No & No & No & No & No & No \\
\hline $\begin{array}{l}\text { Neurosensory } \\
\text { hearing loss }\end{array}$ & Yes (90\%) & Yes $(5-20 \%)$ & No & No & Yes & No & No \\
\hline Renal & $\begin{array}{l}\text { Glomerulo- } \\
\text { sclerosis }\end{array}$ & Structural renal abnormalities & No & No & $\begin{array}{l}\text { Diabetic } \\
\text { nephropathy }\end{array}$ & No & No \\
\hline Diabetes & T2DM (90\%) & T2DM (5-15\%) & No & No & $\begin{array}{l}\text { Diabetes } \\
\text { insipidus, } \\
\text { insulin-dependent } \\
\text { diabetes mellitus }\end{array}$ & No & No \\
\hline Hypogonadism & Yes & Yes & No & No & No & No & Yes \\
\hline $\begin{array}{l}\text { Mental } \\
\text { development }\end{array}$ & Normal/delayed & $\begin{array}{l}\text { Mental } \\
\text { retardation (50\%) }\end{array}$ & Normal/delayed & Normal/delayed & $\begin{array}{l}\text { Normal, } \\
\text { behavior } \\
\text { problems }\end{array}$ & $\begin{array}{l}\text { Moderate-to- } \\
\text { severe delay }\end{array}$ & $\begin{array}{l}\text { Mental } \\
\text { retardation }\end{array}$ \\
\hline $\begin{array}{l}\text { Hepatic } \\
\text { Urologic }\end{array}$ & $\begin{array}{l}\text { Steatosis cirrhosis } \\
\text { Varying degrees } \\
\text { of urinary } \\
\text { problems }(25 \%)\end{array}$ & Steatosis & No & No & $\begin{array}{l}\text { No } \\
\text { Urinary atony }\end{array}$ & No & No \\
\hline Orthopedic & $\begin{array}{l}\text { Short fingers, } \\
\text { wide flat feet, } \\
\text { scoliosis }\end{array}$ & Poly-, brachy-, and syndactyly & Normal & Normal & Normal & $\begin{array}{l}\text { Narrow hands } \\
\text { and feet, tapered } \\
\text { fingers }\end{array}$ & $\begin{array}{l}\text { Postaxial } \\
\text { polydactyly, } \\
\text { scoliosis }\end{array}$ \\
\hline Head & No & $\begin{array}{l}\text { High-arched palate, } \\
\text { hypodontia }\end{array}$ & No & No & No & $\begin{array}{l}\text { Characteristic } \\
\text { facial features }\end{array}$ & $\begin{array}{l}\text { Absent incisors, } \\
\text { microcephaly, } \\
\text { characteristic } \\
\text { facial features }\end{array}$ \\
\hline Genetic & ALMS1 (2p13) & $\begin{array}{l}\text { BBS } 1(11 q 13) \text { BBS } 2(16 q 21) \\
\text { BBS } 3(3 q 11) \text { BBS } 4(15 q 22) \\
\text { BBS } 5(2 q 31) \text { BBS } 6(20 p 12) \\
\text { BBS } 7(4 q 27) \text { BBS } 8(14 q 32) \\
\text { BBS } 9(7 p 14) \text { BBS } 10(12 q 21) \\
\text { BBS } 11 \text { (9q31) BBS } 12(4 q 27)\end{array}$ & CNGA3 $(2 q 11)$ & $\begin{array}{l}\text { LCA1 (17p13), LCA2 (1p31), } \\
\text { LCA3 (14q23), LCA4 (17p13), } \\
\text { LCA5 (6q11-16), LCA6 (14q11), } \\
\text { LCA7 (19q3), LCA8 (1q31), } \\
\text { LCA9 (1p36), LCA10 (12q21), } \\
\text { LCA11 (7q31) }\end{array}$ & WFS1 (4p16) & $\mathrm{COH} 1(8 \mathrm{q} 22)$ & \\
\hline
\end{tabular}

Abbreviation: T2DM, type 2 diabetes mellitus. 
Table 3 Initial assessment and follow-up for Alström Syndrome

\begin{tabular}{|c|c|c|c|c|}
\hline $\begin{array}{l}\text { Organ system } \\
\text { or clinical } \\
\text { problem }\end{array}$ & Evaluation & Regular assessments & $\begin{array}{l}\text { Consider additionally, } \\
\text { if indicated by symptoms }\end{array}$ & Interventional options \\
\hline Vision & $\begin{array}{l}\text { ERG } \\
\text { Visual acuity } \\
\text { Fundus examination }\end{array}$ & $\begin{array}{l}\text { Once, as soon as } \\
\text { old enough to aid } \\
\text { diagnosis } \\
1-3 \text { yearly } \\
1-3 \text { yearly }\end{array}$ & & $\begin{array}{l}\text { Medical counseling } \\
\text { Visual aids with dark } \\
\text { glasses while photophobia } \\
\text { Early teaching of non-visual } \\
\text { language skills }\end{array}$ \\
\hline Respiratory & PFT & $\begin{array}{l}1-3 \text { yearly, if old } \\
\text { enough }\end{array}$ & $\begin{array}{l}\text { Chest } \mathrm{X} \text {-ray In the case of } \\
\text { surgery and/or severe } \\
\text { disease, monitoring of } \\
\mathrm{O}_{2} \text {-saturation, polysomnography }\end{array}$ & $\begin{array}{l}\text { CPAP or BiPAP for } \\
\text { sleep-apnea }\end{array}$ \\
\hline Renal & $\begin{array}{l}\text { Renal function tests } \\
\text { (creatinine, BUN) }\end{array}$ & $\begin{array}{l}\text { Initial assessment } \\
\text { in childhood, } \\
\text { Yearly, if over } \\
14 \text { years old }\end{array}$ & $\begin{array}{l}\text { Uric acid, 24-h urine albumin, } \\
\text { Creatinine-clearance } \\
\text { Ultrasonography if indicated } \\
\text { by abnormal blood chemistry }\end{array}$ & $\begin{array}{l}\text { Medications, dialysis, } \\
\text { kidney transplant }^{\mathrm{a}}\end{array}$ \\
\hline Endocrine & $\begin{array}{l}\text { Fasting glucose, } \\
\text { HbA1c, TSH } \\
\text { Gonadal function in } \\
\text { males (LH, FSH, } \\
\text { testosterone) }\end{array}$ & $\begin{array}{l}\text { Yearly, from } \\
3 \text { years age } \\
1-3 \text { yearly from } \\
12 \text { years of age }\end{array}$ & $\begin{array}{l}\text { OGTT, insulin, FT4, GH, IGF-1, } \\
17-\beta \text {-estradiol, progesterone (females) } \\
\text { Lower abdominal (females) or } \\
\text { testicular (males) US. Pituitary NMR, } \\
\text { hand X-ray (bone age) }\end{array}$ & $\begin{array}{l}\text { Diet, exercise, weight } \\
\text { control medications } \\
\text { (diabetes hypothyroidism, } \\
\text { hypogonadism, growth } \\
\text { hormone deficiency) }\end{array}$ \\
\hline Neurologic & Vestibular function & Yearly, in childhood & $\begin{array}{l}\text { Neurological evaluation } \\
\text { EEG } \\
\text { Brain NMR }\end{array}$ & \\
\hline Urologic & Urine analysis & $1-3$ yearly & $\begin{array}{l}\text { If history of urologic problems, } \\
\text { dynamic tests for urological } \\
\text { function }\end{array}$ & $\begin{array}{l}\text { Medications, self- } \\
\text { catheterization, } \\
\text { surgery }\end{array}$ \\
\hline Orthopedic & $\begin{array}{l}\text { Check for skeletal } \\
\text { abnormalities, } \\
\text { flat feet, scoliosis, kyphosis }\end{array}$ & Yearly & X-ray & $\begin{array}{l}\text { Orthopedic bracing, } \\
\text { surgery }\end{array}$ \\
\hline
\end{tabular}

Abbreviations: ERG, electroretinogram; ECG, electrocardiogram; BP, blood pressure; OAE, otoacoustic emissions; CPAP, continuous positive airway pressure;BiPAP, bilevel positive airway pressure; US, ultrasonography; GERD, gastrointestinal reflux disease; BUN, blood urea nitrogen; TSH, thyroidstimulating hormone; FT4, free thyroxine; LH, luteinizing hormone; FSH, follicle-stimulating hormone; NMR, nuclear magnetic resonance imaging; PFT, pulmonary function testing; EGD, esophagogastroduodenoscopy; TIPS, transjugular intrahepatic portosystemic shunt.

Follow-up should be programmed according to clinical picture and general guidelines. There may be a need for further parameters to monitor, depending on medication.

${ }^{a}$ Organ transplantation has been tried and is still under investigation.

encouraged to seek contact with good sources of support and information, such as Alström Syndrome International (www.jax.org/alstrom) or other groups assisting families with this rare disorder (see Further Information).

\section{Genetics/genetic counseling}

Alström Syndrome is autosomal recessive; therefore, the birth of an affected child establishes each parent as a heterozygous carrier. Carriers of mutations in ALMS1 do 
not show any signs of the disease. In most cases, there is no previous family history of the condition.

Once parents have had a child with Alström Syndrome, there is a $25 \%$ chance, with each subsequent pregnancy, for another child to inherit both copies of the mutated alleles and be affected, $50 \%$ will be carriers, and $25 \%$ may receive both 'normal' ALMS1 alleles. There are certain ethnic groups that are more likely to carry certain specific ALMS1 mutations due to founder effects. As expected, in communities with a high rate of consanguinity, there is increased risk for Alström Syndrome.

ALMS1 is a very large gene and complete sequencing is time consuming and expensive. Therefore, we recommend a screening strategy that targets the regions of ALMS1 where most of the mutations are seen (exons 16, 10, part of 8). If no mutation is identified in these areas, the remaining genomic regions can be sequenced on a research basis. The sensitivity of this approach is approximately $65 \%$, that is, in about $42 \%$ of all patients both mutations will be detected, in about half of the patients, only one of the two mutations will be found, and in about $10 \%$ of the patients, none of the mutations will be found. As a consequence, the possible results of genetic testing must be interpreted within the context of the clinical picture as follows:

- When two mutations are found, this is positive proof of Alström Syndrome. The parents should also be tested to confirm that one of each of the two mutations is inherited from the father and the other from the mother.

- When one mutation is found together with clinical signs of Alström Syndrome, this can be interpreted as very strong evidence for the confirmation of the diagnosis. However, it has to be taken into account that about $0.25 \%$ of all healthy individuals could also show this result.

- When no mutation is found, this by no means excludes the diagnosis. Clinical evaluation of the developing child is particularly important in these patients and diagnosis must be established according to clinical data (Tables 1a and 3). Lack of genetic confirmation should in no way impede recommended monitoring and treatment. However, continuing the search for rare mutations should be considered, to reduce misdiagnosis and reduce concerns about misdiagnosis in these patients and their families.

\section{Prenatal diagnosis}

If the mutation in the index case is known, first trimester chorionic villus sampling or amniocentesis and molecular genetic diagnosis is an option. Indirect testing by linkage analysis is also offered by some laboratories.

\section{Further information}

Licensed genetic testing laboratories

- Centro de Genética Clínica, Porto and Lisbon, Portugal
- Department of Medical and Surgical Sciences, University School of Medicine, Padua, Italy

- West Midlands Regional Genetics Laboratory, Birmingham Women's Hospital, Birmingham, UK

- Clinical Molecular Genetics Laboratory, St James's University Hospital, Leeds, UK.

\section{Laboratories accepting samples on a research basis}

- The Jackson Laboratory, Bar Harbor, ME, USA

\section{Contact information for support organizations}

Alström Syndrome International 14 Whitney Farm Road Mount Desert, ME 04660, USA

E-mail: jan.marshall@jax.org

Web: www.jax.org/alstrom

Alström Syndrome-Brazil SOSW 104 B1 'D' Apt. 104

Setor Sudoesta

Brasilia - DF

Brazil 70670-404

E-mail: asibrasil@asibrasil.com

Web: http://www.asibrasil.com

Alström Syndrome-Canada

RR\#2 Box 204

Finch, Ontario, Canada KOC 1K0

Email: Randy.Douglas@nbpcd.com

France Alström

70 bis rue du Général de Gaulle 95370

Montigny Les Cormeilles

Email: france.alstrom@free.fr

Web: http://france.alstrom.free.fr/

Alström Syndrome-Japan

5-23 Karasubashichou

Fushimiku Daigo

Kyoto, Japan 601-1315

Email: love@rei-rei.sakura.ne.jp

Web: http://rei-rei.net/

Alström Syndrome UK

49 Southfield Avenue

Paignton

S Devon, UK TQ3 1LH

E-mail: alstrom@syndromeuk.freeserve.co.uk

Web: www.alstrom.org.uk

\section{Conclusion}

The ongoing accumulation and sharing of information about Alström Syndrome continues to improve our ability to make valid diagnoses and to find the best combination 
of therapeutic approaches for each child. In the coming years, researchers will undoubtedly identify the mechanisms by which disease alleles of ALMS1 cause the various pathologies observed in Alström Syndrome. Full understanding of the phenotypic characteristics, particularly with the help of existing mouse models, ${ }^{28-30}$ will lead to better insight into the pathophysiology of ALMS1 and may position us to prevent and treat certain debilitating aspects of Alström Syndrome by developing targeted therapies that will address the challenges posed by this multifaceted disorder.

\section{Acknowledgements}

We thank the patients with Alström Syndrome and their families, as well as Alström Syndrome International and colleagues for their continued participation in Alström Syndrome research. Work by JDM and JKN was funded by the National Institutes of Health (HD36878) and the American Diabetes Association. Work by PM was supported from Ministero dell'Università e della Ricerca (MIUR): project PRIN $n^{\circ}$ 2005060325_002.

\section{References}

1 Alström CH, Hallgren B, Nilsson LB, Åsander H: Retinal degeneration combined with obesity, diabetes mellitus and neurogenous deafness: a specific syndrome (not hitherto described) distinct from the Laurence-Moon-Bardet-Biedl syndrome: a clinical, endocrinological and genetic examination based on a large pedigree. Acta Psychiatr Neurol Scand Suppl 1959; 129: $1-35$.

2 Marshall JD, Bronson RT, Collin GB et al: New Alström syndrome phenotypes based on the evaluation of 182 cases. Arch Intern Med 2005; 165: 675-683.

3 Alter CA, Moshang Jr T: Growth hormone deficiency in two siblings with Alstrom syndrome. Am J Dis Child 1993; 147: 97-99.

4 Maffei P, Munno V, Marshall JD et al: The Alström syndrome: is it a rare or unknown disease? Ann Ital Med Int 2002; 17: 221-228.

5 Maffei P, Boschetti M, Marshall JD et al: Characterization of the IGF system in 15 patients with Alström syndrome. Clin Endocrinol (Oxf) 2007; 66: 269-275.

6 Paisey RB, Carey CM, Bower L et al: Hypertriglyceridaemia in Alstrom's syndrome: causes and associations in 37 cases. Clin Endocrinol (Oxf) 2004; 60: 228-231.

7 Koray F, Dorter C, Benderli Y et al: Alström syndrome: a case report. J Oral Sci 2001; 43: 221-224.

8 Goldstein JL, Fialkow PJ: The Alström syndrome. Report of three cases with further delineation of the clinical, pathophysiological, and genetic aspects of the disorder. Medicine 1973; 52: 53-71.

9 Charles S, Moore A, Yates J, Green T, Clark P: Alstrom's syndrome: further evidence of autosomal recessive inheritance and endocrinological dysfunction. J Med Genet 1990; 27: 590-592.

10 Edwards JA, Sethi PK, Scoma AJ, Bannerman RM, Frohman LA: A new familial syndrome characterized by pigmentary retinopathy, hypogonadism, mental retardation, nerve deafness and glucose intolerance. Am J Med 1976; 60: 23-32.

11 Dyer DS, Wilson ME, Small KW, Pai GS: Alström syndrome: a case misdiagnosed as Bardet-Biedl syndrome. I Pediatr Ophthalmol Strabismus 1994; 3: 272-274.
12 Hauser C, Rojas C, Roth A, Schmied E, Saurat JH: A patient with features of both Bardet-Biedl and Alström syndromes. Eur J Pediatr 1990; 149: 783-785.

13 Marshall JD, Ludman MD, Shea SE et al: Genealogy, natural history, and phenotype of Alström syndrome in a large Acadian kindred and three additional families. Am J Med Genet 1997; 73: $150-161$.

14 Russell-Eggitt IM, Clayton PT, Coffey R et al: Alström syndrome. Report of 22 cases and literature review. Ophthalmology 1998; 105: $1274-1280$

15 Deeble VJ, Roberts E, Jackson A, Lench N, Karbani G, Woods CG: The continuing failure to recognise Alström syndrome and further evidence of genetic homogeneity. J Med Genet 2000; 37: 219.

16 Hopkinson I, Marshall JD, Paisey RB, Carey C, MacDermott S: Alström syndrome http//www.genetests.org, 2007.

17 Collin GB, Marshall JD, Ikeda A et al: Mutations in ALMS1 cause obesity, type 2 diabetes and neurosensory degeneration in Alström syndrome. Nat Genet 2002; 31: 74-78.

18 Hearn T, Renforth GL, Spalluto C et al: Mutation of ALMS1, a large gene with a tandem repeat encoding 47 amino acids, causes Alström syndrome. Nat Genet 2002; 31: 79-83.

19 Li G, Vega R, Nelms K et al: A role for Alström syndrome protein, alms1, in kidney ciliogenesis and cellular quiescence. PLoS Genet 2007; 3: e8.

20 Hearn T, Spalluto C, Phillips VJ et al: Subcellular localization of ALMS1 supports involvement of centrosome and basal body dysfunction in the pathogenesis of obesity, insulin resistance, and type 2 diabetes. Diabetes 2005; 54: 1581-1587.

21 Kinoshita T, Hanaki K, Kawashima Y et al: A novel non-sense mutation in Alström syndrome: subcellular localization of its truncated protein. Clin Pediatr Endocrinol 2003; 12: 114.

22 Titomanlio L, De Brasi D, Buoninconti A et al: Alström syndrome: intrafamilial phenotypic variability in sibs with a novel nonsense mutation of the ALMS1 gene. Clin Genet 2004; 65: $156-157$.

23 Bond J, Flintoff K, Higgins J et al: The importance of seeking ALMS1 mutations in infants with dilated cardiomyopathy. J Med Genet 2005; 42: e10.

24 Minton JA, Owen KR, Ricketts CJ et al: Syndromic obesity and diabetes: changes in body composition with age and mutation analysis of ALMS1 in 12 United Kingdom kindreds with Alström syndrome. J Clin Endocrinol Metab 2006; 91: 3110-3116.

25 Marshall JD, Hinman EG, Collin GB et al: Spectrum of ALMS1 variants and evaluation of genotype-phenotype correlations in Alström syndrome. Hum Mutat 2007 (e-pub ahead of print, 26 June 2007).

26 Patel S, Minton JA, Weedon MN et al: Common variations in the ALMS1 gene do not contribute to susceptibility to type 2 diabetes in a large white UK population. Diabetologia 2006; 49: $1209-1213$.

27 Görler H, Warnecke G, Cebotari S et al: Heart-lung transplantation in a 14-year old boy with Alström syndrome. J Heart Lung Transp (in press).

28 Collin GB, Cyr E, Bronson $\mathrm{R}$ et al: Alms1-disrupted mice recapitulate human Alström syndrome. Hum Mol Genet 2005; 14: $2323-2333$.

29 Arsov T, Silva DG, O'Bryan MK et al: Fat Aussie-a new Alström Syndrome mouse showing a critical role for Alms1 in obesity, diabetes and spermatogenesis. Mol Endocrinol 2006; 20: $1610-1622$.

30 Arsov T, Larter CZ, Nolan CJ et al: Adaptive failure to high-fat diet characterizes steatohepatitis in Alms1 mutant mice. Biochem Biophys Res Commun 2006; 342: 1152-1159. 